\title{
Effects of climate variability on insect pests of cabbage: adapting alternative planting dates and cropping pattern as control measures
}

\author{
Clovis B. Tanyi ${ }^{*}$, Christopher Ngosong and Nelson N. Ntonifor
}

\begin{abstract}
Background: Considering the potential impact of climate change on the ecology of insect pests, different planting dates and cropping patterns were investigated as farm-level adaption to control insect pests of cabbage and improve productivity.

Methods: This is a $3 \times 4$ factorial experiment setup in randomized complete block design including three planting dates (early, normal and late) and four cropping patterns (control—sole cabbage or tomato, tomato intercrop, Piper emulsion and insecticide) with four replications each.

Results: Cabbage infestation ranged from 1 to 29 and correlated negatively with planting dates or treatments, which differed $(P<0.001)$ significantly across planting dates, treatments and their interaction, with the highest during early planting. Diamondback moth larvae correlated negatively with planting dates or treatments, ranging from 0 to 13 that differed significantly $(P<0.001)$ across planting dates, treatments and their interaction. Looper larvae correlated negatively with treatments, ranging from 0 to 8 that differed significantly $(P<0.001)$ across planting dates, treatments and their interaction, with highest during normal planting and lowest during late planting. Webworm larvae correlated negatively with planting dates or treatments, ranging from 0 to 13 that differed significantly $(P<0.001)$ across planting dates, treatments and their interaction. The number of sprouted plants ranged from 0 to 6 and differed significantly $(P<0.001)$ across planting dates, treatments and their interaction, with the highest in early planting for control that differed significantly from late planting. Cabbage yield correlated positively with planting dates and ranged from 2.8 to 6.0 tons per hectare that differed significantly $(P<0.001)$ across planting dates, treatments and their interaction, with the highest during normal and late planting dates.

Conclusion: The interaction of planting dates and Piper emulsion or intercropping treatments can be effectively used as control measure for insect pests of cabbage leading to greater yield, with late planting as viable farm-level adaptation to climate variability.
\end{abstract}

Keywords: Climate change, Diamondback moth, Intercropping, Piper botanical, Planting date

\section{Background}

Climate variability poses constraints on agricultural production with significant effects on cropping seasons and food security [1]. Sub-Saharan Africa (SSA) is more vulnerable to climate change due to its reliance on agriculture that is highly sensitive to climate variables, and the

*Correspondence: tanyi.clovis@yahoo.com

Department of Agronomic and Applied Molecular Sciences, Faculty of Agriculture and Veterinary Medicine, University of Buea, P.O.Box 63, Buea, South West Region, Cameroon low capacity for adaptation [2]. Climate change affects most crops including vegetables that are sensitive to climate shocks [3]. Extreme weather events such as heavy rainfall, droughts and heat waves have increased in recent decades, with significant implications on agricultural productivity $[4,5]$. Periodic droughts and changes in rainfall frequency or severity can severely influence the ecology of insect pests in arable fields [6-8]. In view of current global climate change scenarios, there is overdue 
need for sustainable adaptive farm management strategies [9].

Many insect pests hinder cabbage (Brassica oleracea L.) cultivation and the most damaging is Diamondback moth-DBM (Plutella xylostella L.) (Lepidoptera: Plutellidae) that causes up to $90 \%$ yield loss [10]. DBM, Looper Trichoplusia ni (Hübner) (Lepidoptera: Noctuidae) and webworm Hellula undalis (Fabricius) (Lepidoptera: Pyralidae) can cause sprouting, contamination with frass, or even kill young plants [11]. Reliance on synthetic insecticides to control crop pests usually leads to environmental pollution, pest resistance and high production costs [12-16]. The prevention, avoidance, monitoring and suppression (PAMS) model was successfully used to evaluate pest management strategies [17]. Prevention involves crop rotation and use of resistant cultivars, while avoidance involves alternative planting dates and intercropping [17, 18]. Tomato intercrop [18-20], botanicals and planting dates [21-24] have demonstrated efficacy and cost-effectiveness as control measures for cabbage pests.

Climate variability was projected to cause varying effects on crops including significant yield decrease in eight agricultural regions across Cameroon [25, 26]. Despite limitations in climate data for the study area, recent meteorological data showed significant weather variations with increased annual temperature from $26^{\circ} \mathrm{C}$ in 2010 to $27.2^{\circ} \mathrm{C}$ in 2012 and 2014, while annual rainfall decreased from $3135 \mathrm{~mm}$ in 2013 to $1993 \mathrm{~mm}$ in 2014 [27]. These temperature and rainfall fluctuations can affect farming systems by disrupting the normal planting schedule. Consequently, alternative planting and harvesting dates were suggested as potential farm-level adaptations to climate variability in this study area and across Cameroon [28]. Accordingly, Ngondjeb [29] advocated effective agricultural planning for the impact of climate variability in Cameroon. It is therefore important to consider the effects of climate variability on the ecology of insect pests in arable systems, and potential integrated management approach involving alternative planting dates and cropping patterns. Hence, this study was intended to adapt alternative planting dates and cropping pattern as control measures for cabbage pests under climate change scenarios. It was hypothesized that shifting from normal to late planting dates, and the interaction of planting dates and treatments will lead to significant reduction of insect pests and increased cabbage yield.

\section{Methods}

\section{Experimental site and setup}

This study was conducted at the research and teaching farm of the Faculty of Agriculture and Veterinary Medicine, University of Buea. The site is located in Molyko
Buea, situated between latitudes $4^{\circ} 3^{\prime} \mathrm{N}$ and $4^{\circ} 12^{\prime} \mathrm{N}$ and longitudes $9^{\circ} 12^{\prime} \mathrm{E}$ and $9^{\circ} 20^{\prime} \mathrm{E}$. The soil is derived from weathered volcanic rocks dominated by silt, clay and sand $[30,31]$. The rainfall regime is mono-modal with less pronounced dry season and $85-90 \%$ relative humidity, and the dry season starts from November to March [32]. It has a mean annual rainfall of $2800 \mathrm{~mm}$ and monthly air temperature ranging from 19 to $30^{\circ} \mathrm{C}$, while soil temperature at $10 \mathrm{~cm}$ depths decreases from 25 to $15^{\circ} \mathrm{C}$ with increasing elevation from 200 to $2200 \mathrm{~m}$ above sea level, respectively [30, 33, 34]. Mean monthly temperature ranged from 17.3 to $19.7^{\circ} \mathrm{C}$ and precipitation from 30 to $429 \mathrm{~mm}$ in Buea during the experimental period (Table 1).

This is a $3 \times 4$ factorial experiment setup in randomized complete block design including three planting dates (early-24th January 2016, normal-10th March 2016 and late-15th April 2016) and four cropping patterns (control-sole cabbage or sole tomato, tomato intercrop, Piper emulsion and insecticide) with four replications each. The experimental field was cleared manually using a cutlass and partitioned into 16 plots measuring $3 \times 4 \mathrm{~m}$ each $\left(12 \mathrm{~m}^{2}\right)$, and manually tilled at about $30 \mathrm{~cm}$ depth using a hoe. The sole cabbage plots contained 8 rows and 6 columns of cabbage plants at $50 \times 50 \mathrm{~cm}$ inter- and intra-row spacing, leading to 48 plants per plot. Cabbage-tomato intercrop plots contained 4 rows and $3 \mathrm{col}-$ umns of cabbage and tomato plants each, leading to 48 plants per plot (24 plants per crop). These were planted at $50 \times 50 \mathrm{~cm}$ inter- and intra-row spacing on one alternate row between cabbage and tomato plants. A non-tilled 50 -cm buffer zone separated the experimental plots from each other.

Table 1 Mean monthly temperature and precipitation in Buea during the experimental period

\begin{tabular}{lll}
\hline Months & Temperature $\left({ }^{\circ} \mathbf{C}\right)$ & Rainfall $(\mathbf{m m})$ \\
\hline January & 19 & 30 \\
February & 19.4 & 65 \\
March & 19.7 & 161 \\
April & 19.6 & 188 \\
May & 19.1 & 244 \\
June & 18.3 & 264 \\
July & 17.3 & 429 \\
August & 17.4 & 488 \\
September & 17.7 & 482 \\
October & 18.3 & 323 \\
November & 18.8 & 112 \\
December & 18.9 & 29 \\
\hline
\end{tabular}

Source: https://en.climate-data.org/africa/cameroon/southwest/buea-3985/ 


\section{Plant cultivation}

Hybrid cabbage (F1 Green Coronet; STARKE AYRES ${ }^{\circledR}$, France; that are heat and cold resistant) and tomato (F1 Cobra 26; TECHNISEM ${ }^{\circledR}$, France; adapted for Sahelian and tropical areas with tolerance to disease and high productivity) seeds were purchased from an agro-shop in Buea Cameroon. The F1 Green Coronet seeds and F1 Cobra 26 seeds were pre-germinated on separate beds at $15 \times 15 \mathrm{~cm}$ inter-row spacing on nearby $2.5 \times 1 \mathrm{~m}$ nursery beds that were cleared using cutlasses and tilled manually using hoes, and manually irrigated using a watering can. For all planting dates, vigorous cabbage seedlings of similar sizes were transplanted from the nursery, followed by tomato transplant 2 weeks later. After transplanting, all plots were manually irrigated every 2 days to maintain optimum soil moisture for plant growth and performance.

Both cabbage and tomato nurseries were amended with $0.5 \mathrm{~kg}$ inorganic fertilizer NPK 20:10:10+CaO $\left(\right.$ ADER $^{\circledR}$ Cameroon), and treated with a mixture of synthetic insecticides and fungicides. $35 \mathrm{~mL}$ insecticide (K-Optimal; SCPA SIVEX International ${ }^{\circledR}$ France; comprising $15 \mathrm{~g} / \mathrm{L}$ lambda - cyhalothrine $+20 \mathrm{~g} / \mathrm{L}$ acetamiprid active ingredients) and $100 \mathrm{~g}$ fungicide (Mancozan super; SCPA SIVEX International ${ }^{\circledR}$ France; comprising $640 \mathrm{~g} / \mathrm{kg}$ mancozeb $+80 \mathrm{~g} / \mathrm{kg}$ metalaxyl active ingredients) were dissolved in $15 \mathrm{~L}$ water and applied using a knapsack sprayer. After transplanting, all experimental plots were manually irrigated every 2 days to maintain optimum soil moisture for plant growth and performance. Weed emergence was monitored regularly on all experimental plots and weeded manually using a hoe.

\section{Fertilizer amendment}

All experimental plots were amended with the same type and amount of soil applied organic and inorganic fertilizers. Organic poultry dropping (obtained from a poultry farm in Molyko Buea) was broadcasted on all experimental plots 7 days before the crops were transplanted. Thirty days after transplanting, inorganic NPK 20:10:10+ $\mathrm{CaO}$ (ADER ${ }^{\circledR}$ Cameroon) was applied on all experimental plots at $5 \mathrm{~g}$ per plant by ringing at $5 \mathrm{~cm}$ from plants.

\section{Insecticides and fungicides}

The synthetic plots were sprayed with commercial insecticide (K-Optimal; SCPA SIVEX International ${ }^{\circledR}$ France) and fungicide (Mancozan super; SCPA SIVEX International ${ }^{\circledR}$ France). The cabbage-tomato intercrop plots were not sprayed with Piper emulsion or synthetic insecticide and the tomato plants served as repellent or attractant of cabbage pests. Neither Piper emulsion nor synthetic insecticide was applied in the sole cabbage or sole tomato control plots.

\section{Piper emulsion botanical}

The organic Piper emulsion botanical comprised West African black pepper (Piper guineense) that was harvested from a primary forest at Inokun-Eyumojock in South-western Cameroon and prepared according to Tanyi et al. [35]. Briefly, $250 \mathrm{~g}$ crushed sun-dried Piper seed powder was dissolved in $1 \mathrm{~L}$ vegetable oil $\left(\mathrm{KING}^{\prime} \mathrm{S}^{\circledR}\right.$, Lagos-Nigeria) and $10 \mathrm{~g}$ detergent $\left(\mathrm{SABA}^{\circledR}\right.$, DoualaCameroon) was added to produce a sticky emulsion. The mixture was stirred thoroughly and stored in a plastic container at room temperature while laboratory tests were conducted to determine the effective dose for best field results. $50 \mathrm{~mL}$ Piper emulsion was filtered using a double 169-folded muslin cloth and diluted in $15 \mathrm{~L}$ water for field application every 2 weeks, during cold dry early morning periods with minimal drift. Piper emulsion was stirred thoroughly to achieve homogeneity and sprayed using a knapsack sprayer on both sides of cabbage leaves for all 192 plants in the respective plots.

\section{Data collection on cabbage pests}

Cabbage plants were assessed for pest infestation before and after heading, while the wrapper leaves were monitored regularly for symptoms of pest damage. Five randomly selected plants were tagged on each plot, and visible signs of damage and occurrence of insect pest larvae were assessed and data presented as number of larvae per plant (mean $\pm \mathrm{SD}$ ). Cabbage plants were identified as infested based on observation of diamondback moth, looper and webworm larvae or their damage, and reported as number of infested plants per treatment (mean $\pm \mathrm{SD})$. Diamondback moth (P.xylostella) is an important cabbage pest with average development time of 25-30 days from egg to pupal stage depending on weather conditions, and a complete cycle of 17-51 days from egg to adult. The annual number of generations varies from four in cold climates to 12 in warm climates. Diamondback moth was assessed on wrapper leaves and identified as small round holes, scratches or skeleton damage on leaves with partially damaged epidermis that gives cabbage leaves a windowpane appearance. An adult female cabbage Looper (T. $n i$ ) moth lays from 300 to 600 eggs pale yellow and round eggs in 10-12 days adult lifespan that hatch in 3-10 days, with a more rapid pupal stage in warmer temperatures. The occurrence of webworm larvae and plant damage was identified as leaves held together with silk. Each female cabbage webworm (H. undalis) lays about 75-250 eggs singly or in groups of 2-3 on the inner tissues of host plants. The hatching larvae bore into stems of growing points, weaving webs into which they place their frass. Webworm pupates in soil within webbed cocoons that include soil particles as a generation develops in about $4-5$ weeks at $27^{\circ} \mathrm{C}$, with 
short-lived adults and the potential to complete $7-8$ generations annually.

\section{Data collection on cabbage yield}

Sprouted cabbage plants were assessed and recorded as total number of plants with multiple shoots (sprouts) on each plot and reported as number of sprouted cabbage plants per treatment (mean $\pm S D$ ). Marketable cabbage heads were harvested manually at physical maturity and the yield presented as weight of harvested cabbage heads per treatment $\left(t \mathrm{ha}^{-1}\right.$, mean $\left.\pm \mathrm{SD}\right)$. At harvesting, ten cabbage plants were incised above the soil on each plot and weighed individually using a top loading balance (Brand MK-01, China). Prior to weighing, a cutter was used to remove all damaged leaves.

\section{Statistical analysis}

Datasets were assessed for normality using Kolmogorov-Smirnov and Shapiro-Wilk tests before they were subjected to statistical analyses using STATISTICA 9.1 for Windows [36, 37]. Dependent variables (e.g. cabbage infestation or yield, Diamondback moth, Looper and Webworm) were subjected to multivariate analysis of variance (ANOVA, $P<0.05$ ) to test the effects of planting dates $(n=3)$ and treatments $(n=4)$ as categorical predictors. Significant data means were compared by post hoc Tukey's HSD test $(P<0.05)$, and Spearman rank correlation $(P<0.05)$ was performed to determine the degree of association between dependent variables and categorical predictors.

\section{Results}

\section{Cabbage infestation}

Cabbage infestation ranged from 1 to 29 and correlated negatively with planting dates and treatments, which differed significantly $(P<0.001)$ across planting dates (Fig. 1a), treatments (Fig. 1b) and their interaction. The highest infestation occurred during early planting for the control that differed significantly $(P<0.05)$ from the normal and late plantings (Fig. 1a). Differences occurred over time for intercropping treatment as the early planting differed significantly $(P<0.05)$ from late planting (Fig. 1a). The highest infestation occurred in control that differed significantly $(P<0.05$; Fig. $1 \mathrm{~b})$ from the other treatments. Negative correlations $(P<0.05)$ occurred between cabbage infestation and planting dates $(r=-0.48)$ or treatments $(r=-0.71)$.

\section{Diamondback moth larvae}

Diamondback moth-DBM larvae correlated negatively planting dates or treatments, ranging from 0 to 13 that differed significantly $(P<0.001)$ across planting dates
(Fig. 2a), treatments (Fig. 2b) and their interaction. DBM larvae differed significantly $(P<0.05$; Fig. $2 \mathrm{a})$ across planting dates for control, with highest during early planting and lowest during late planting. Significant $(P<0.05)$ treatment effects occurred during the early and normal planting, with the highest DBM larvae recorded in the control that differed from the other treatments (Fig. 2b). Treatment effects on DBM larvae were significant $(P<0.05)$ during early planting, with highest in control followed by intercropping, Piper emulsion and insecticide (Fig. 2b). Negative correlations $(P<0.05)$ occurred between DBM larvae and planting dates $(r=-0.33)$ or treatments $(r=-0.69)$ with correlations during early $(r=-0.89)$ and late $(r=-0.87)$ plantings.

\section{Looper larvae}

Looper larvae correlated negatively with treatments, ranging from 0 to 8 that differed significantly $(P<0.001)$ across planting dates (Table 2A), treatments (Table 2B) and their interaction, with highest for control during normal planting and lowest during late planting $(P<0.05$; Table $2 \mathrm{~A})$. Negative correlations $(P<0.05)$ occurred between looper larvae and treatments for early $(r=-0.54)$, normal $\left(r^{*}=-0.62\right)$ and late $(r=-0.51)$ plantings.

\section{Webworm larvae}

Webworm larvae correlated negatively with planting dates and treatments, ranging from 0 to 13 that differed significantly $(P<0.001)$ across planting dates (Table $3 \mathrm{~A})$, treatments (Table 3B) and their interaction. Webworm larvae differed significantly $(P<0.05)$ for the control, with the lowest in late planting and highest in early planting (Table 3B). Negative correlations $(P<0.05)$ occurred between webworm larvae and planting dates $(r=-0.54)$ or treatments for early $(r=-0.79)$, normal $\left(r^{*}=-0.75\right)$ and late $(r=-0.51)$ plantings.

\section{Cabbage yield}

Sprouted plants ranged from 0 to 6 and differed significantly $(P<0.001)$ across planting dates (Table $4 \mathrm{~A})$, treatments (Table 4B) and their interaction. The highest number of sprouted plants occurred in early planting for control, which differed significantly $(P<0.05)$ from late planting (Table 4A). Negative correlations $(P<0.05)$ occurred between sprouted plants and planting dates $(r=-0.4)$ or treatments for early $(r=-0.9)$, normal $\left(r^{*}=-0.8\right)$ and late $(r=-0.5)$ plantings. Cabbage yield ranged from 2.8 to 6.0 tons per hectare that correlated $(P<0.05)$ positively with planting dates $(r=0.6)$, and differed significantly $(P<0.001)$ across planting dates (Fig. 3a), treatments (Fig. 3b) and their interaction, with highest during normal and late plantings. The late 


\section{a}

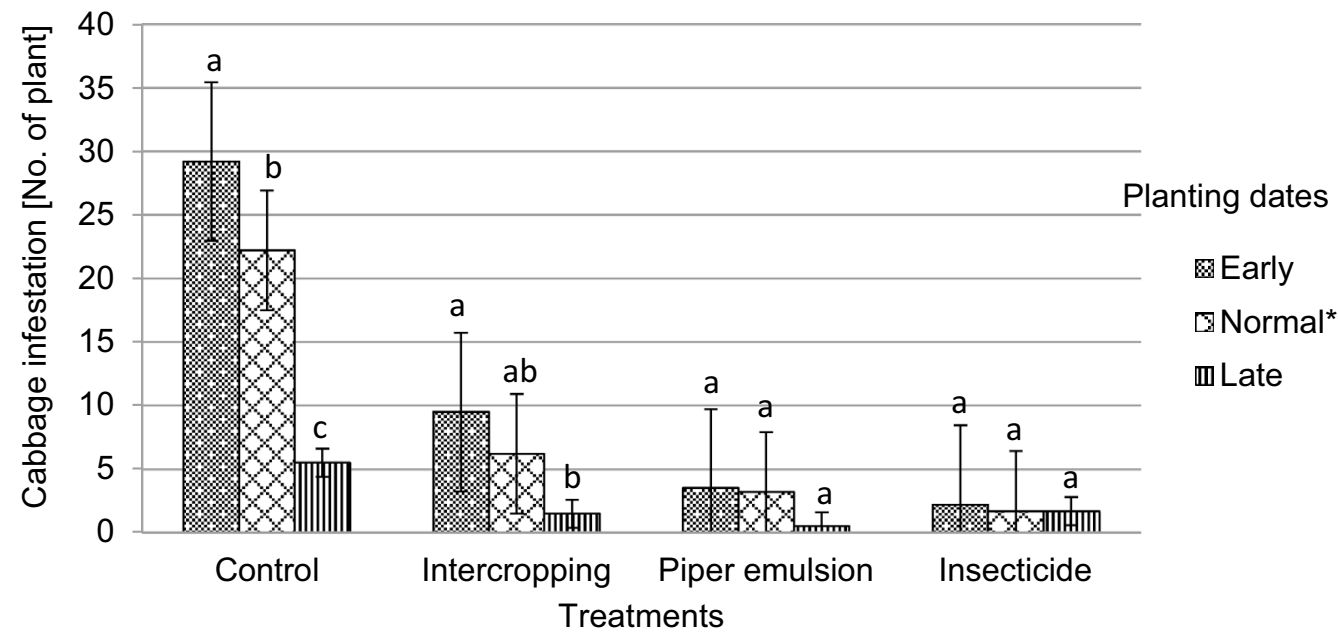

b

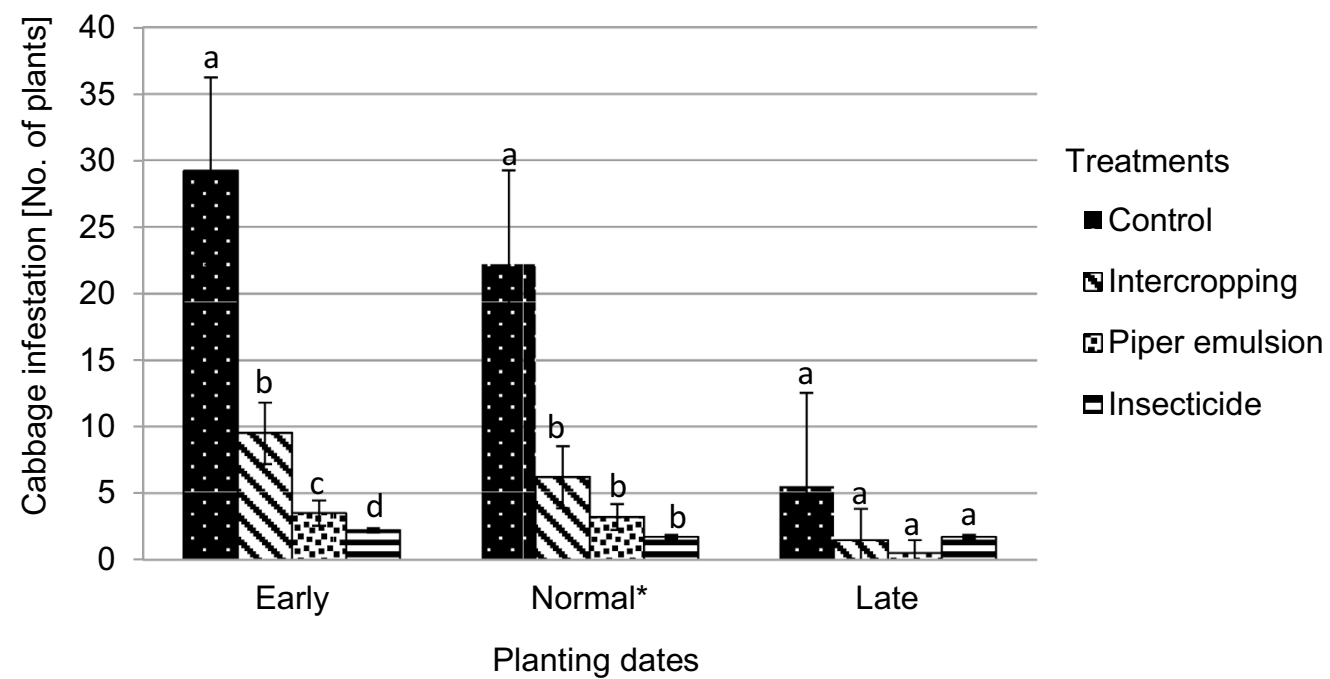

Fig. 1 Effect of planting dates (a) (early, normal and late) and treatments (b) (control, intercropping, Piper emulsion and insecticide) on number of infested cabbage plants (mean \pm SD). Values within treatments or planting dates with different letters are significantly different $(P<0.05)$. ${ }^{*}$ Data from Tanyi et al. [35]

planting differed significantly $(P<0.05)$ from early and normal plantings for the control (Fig. 3).

\section{Discussion}

\section{Effect of planting dates on cabbage pests}

The results of this study are consistent with current trends in climate dynamics, which require adaptation of cropping seasons to the ecology of insect pests, with particular attention on alternative planting dates and sustainable treatments $[6,38]$. These results reflect the overdue need for adapted integrated pest management approaches that incorporate planting dates with local farm management practices under different climate scenarios [39]. The significantly low pest infestation during late planting compared to normal and early plantings can be attributed to current climate dynamics in the study area with decreasing rainfall and increasing temperature [27, 38], and demonstrates the efficacy of alternative planting dates as control measure for cabbage pests [28]. The decrease in diamondback moth larvae from early to late plantings is consistent with other results where diamondback moth occurred in vegetable fields during early and normal planting, but disappeared during late planting [40]. Climate variables play important roles in the ecology of insect pests because of their short generations and high reproductive rates 


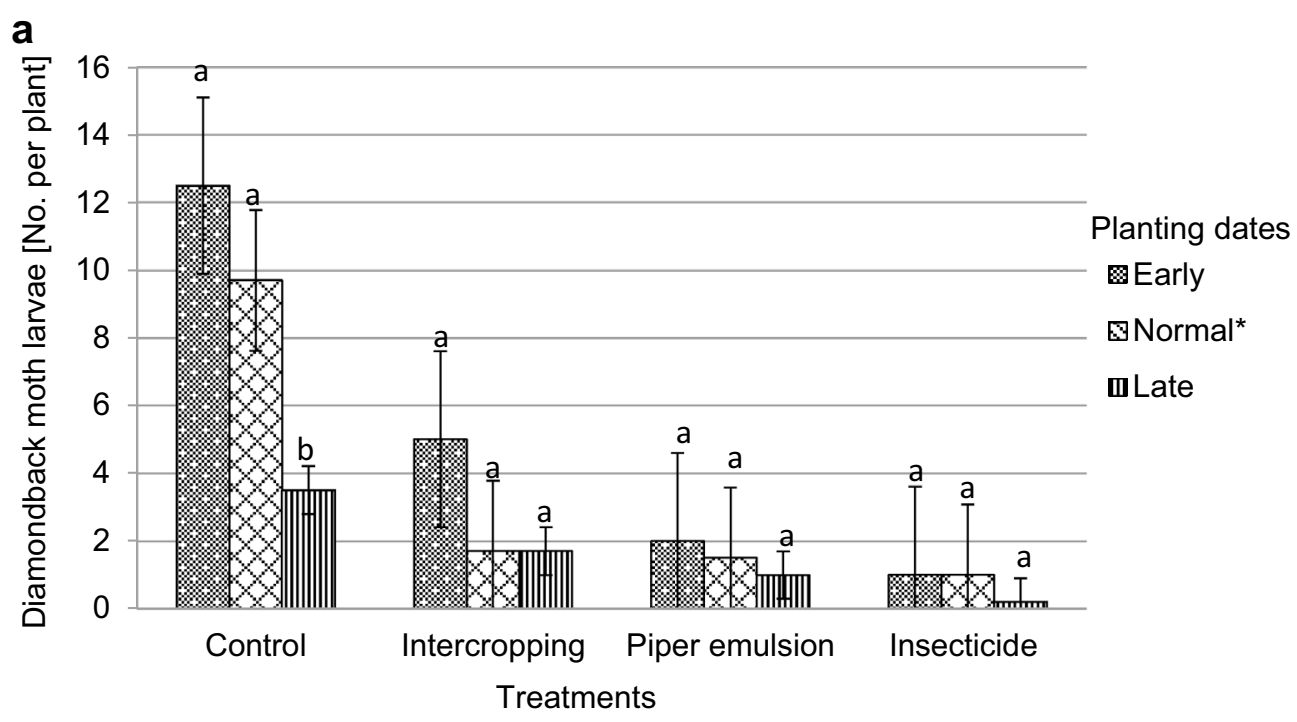

\section{b}

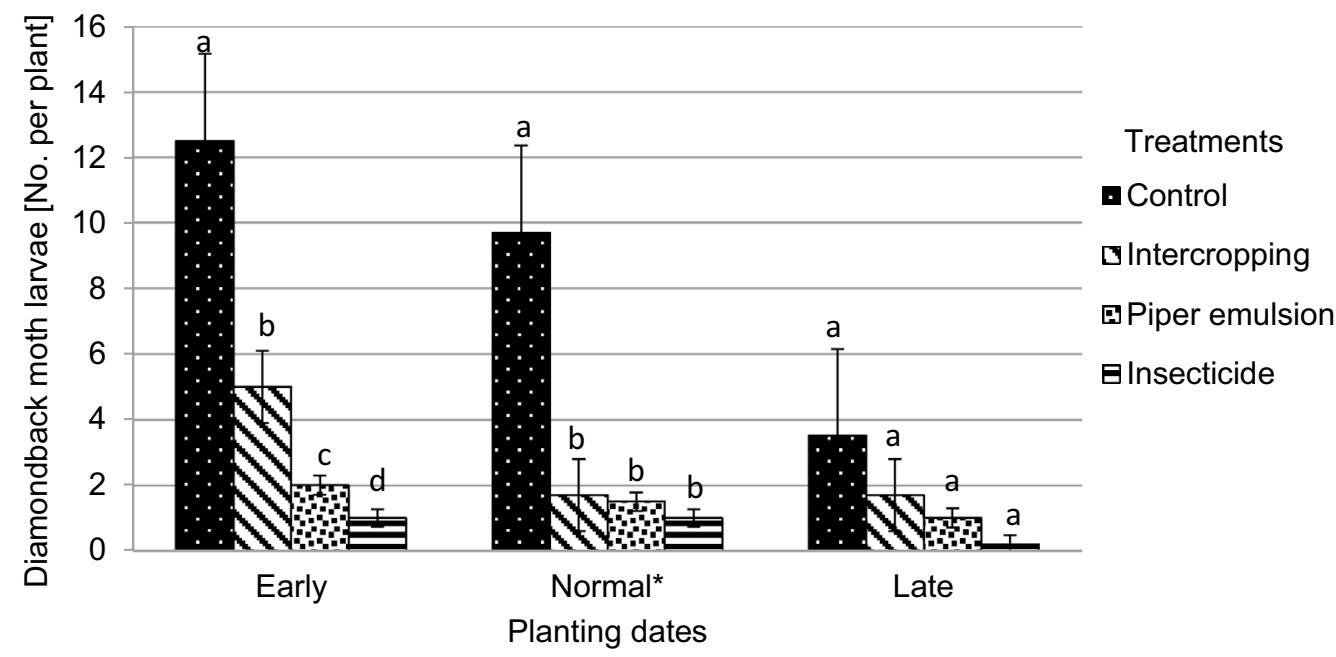

Fig. 2 Effect of planting dates (a) (early, normal and late) and treatments (b) (control, intercropping, Piper emulsion and insecticide) on number of diamondback moth larvae (mean \pm SD). Values within treatments or planting dates with different letters are significantly different $(P<0.05)$. ${ }^{*}$ Data from Tanyi et al. [35]

[41, 42], causing significant effects on crop production in Cameroon that require effective planning [29, 43]. In addition, climate variability reduced parasitism of caterpillars leading to variation in the frequency and intensity of herbivory outbreaks [44]. Temperature effects on insect ecology are variable with high temperatures negatively affecting eggs, while low temperatures negatively affect larvae $[43,45]$. These results are consistent with the first hypothesis of this study and strongly support a shift to late planting as farm-level adaptation to cabbage pests as compared to the current planting date in the study area.
Besides alternative planting dates, farm management practices demonstrated strong importance as control measure for cabbage pests across the different planting dates. Effectiveness of the evaluated crop protection practices is demonstrated by lack of significant differences in cabbage infestation and pest occurrence between different planting dates for intercropping, Piper emulsion and insecticide treatments compared to control $[18,36]$. The low insect pest occurrence across treatments during late planting is consistent with the hypothesis of this study, which strongly suggests a shift from the current planting date as farm-level adaptation to climate variability in the study area. This is commensurate with predictions on the 
Table 2 Effect of planting dates-A (early, normal and late) and treatments-B (control, intercropping, Piper emulsion and insecticide) on number of looper larvae (mean \pm SD)

\begin{tabular}{|c|c|c|c|c|}
\hline \multirow[t]{2}{*}{ Treatments } & \multicolumn{4}{|c|}{ Planting dates } \\
\hline & Early & Normal $^{\mathrm{a}}$ & Late & \\
\hline Control & $6.2 \pm 2.0 \mathrm{a}$ & $8.3 \pm 1.7 a$ & $0.2 \pm 0.5 b$ & \\
\hline Intercropping & $0.2 \pm 0.5 \mathrm{a}$ & $0.2 \pm 0.5 a$ & $0.0 \pm 0.0 \mathrm{a}$ & \\
\hline Piper emulsion & $0.0 \pm 0.0 \mathrm{a}$ & $0.5 \pm 0.5 a$ & $0.0 \pm 0.0 \mathrm{a}$ & \\
\hline Insecticide & $0.7 \pm 0.9 \mathrm{a}$ & $0.7 \pm 0.9 a$ & $0.5 \pm 0.5 \mathrm{a}$ & \\
\hline \multicolumn{5}{|l|}{ B } \\
\hline \multirow[t]{2}{*}{ Planting dates } & \multicolumn{4}{|c|}{ Treatments } \\
\hline & Control & Intercropping & Piper emulsion & Insecticide \\
\hline Early & $6.2 \pm 2.0 \mathrm{a}$ & $0.2 \pm 0.5 a$ & $0.0 \pm 0.0 \mathrm{a}$ & $0.7 \pm 0.9 a$ \\
\hline Normal $^{a}$ & $8.3 \pm 1.7 a$ & $0.2 \pm 0.5 a$ & $0.5 \pm 0.5 \mathrm{a}$ & $0.7 \pm 0.9 a$ \\
\hline Late & $0.2 \pm 0.5 b$ & $0.0 \pm 0.0 \mathrm{a}$ & $0.0 \pm 0.0 \mathrm{a}$ & $0.5 \pm 0.5 a$ \\
\hline
\end{tabular}

Values within rows with different letters are significantly different $(P<0.05)$

${ }^{\text {a }}$ Data taken from Tanyi et al. [35]

Table 3 Effect of planting dates-A (early, normal and late) and treatments-B (control, intercropping, Piper emulsion and insecticide) on number of webworm larvae (Mean \pm SD)

A

\begin{tabular}{|c|c|c|c|c|}
\hline \multirow[t]{2}{*}{ Treatments } & \multicolumn{4}{|c|}{ Planting dates } \\
\hline & Early & Normal $^{a}$ & Late & \\
\hline Control & $12.5 \pm 3.1 \mathrm{a}$ & $5.5 \pm 3.1 b$ & $1.5 \pm 1.7 b$ & \\
\hline Intercropping & $4.5 \pm 2.6 a$ & $4.2 \pm 3.0 \mathrm{a}$ & $0.2 \pm 0.5 a$ & \\
\hline Piper emulsion & $1.5 \pm 2.3 \mathrm{a}$ & $1.2 \pm 0.9 a$ & $0.0 \pm 0.0 \mathrm{a}$ & \\
\hline Insecticide & $1.0 \pm 0.8 \mathrm{a}$ & $0.5 \pm 1.0 \mathrm{a}$ & $0.0 \pm 0.0 \mathrm{a}$ & \\
\hline \multicolumn{5}{|l|}{ B } \\
\hline \multirow[t]{2}{*}{ Planting dates } & \multicolumn{4}{|l|}{ Treatments } \\
\hline & Control & Intercropping & Piper emulsion & Insecticide \\
\hline Early & $12.5 \pm 3.1 \mathrm{a}$ & $4.5 \pm 2.6 a$ & $1.5 \pm 2.3 \mathrm{a}$ & $1.0 \pm 0.8 \mathrm{a}$ \\
\hline Normal $^{\mathrm{a}}$ & $5.5 \pm 3.1 \mathrm{~b}$ & $4.2 \pm 3.0 \mathrm{a}$ & $1.2 \pm 0.9 \mathrm{a}$ & $0.5 \pm 1.0 \mathrm{a}$ \\
\hline Late & $1.5 \pm 1.7 b$ & $0.2 \pm 0.5 a$ & $0.0 \pm 0.0 \mathrm{a}$ & $0.0 \pm 0.0 \mathrm{a}$ \\
\hline
\end{tabular}

Values within rows with different letters are significantly different $(P<0.05)$

a Data taken from Tanyi et al. [35]

ecology of insect pests under climate change scenarios that combine experimental data and modeling of population dynamics [46]. The positive results for interaction of planting dates and treatments support the second hypothesis of this study, and represent a viable farm-level integrated pest management adaptation to current climate dynamics in the study area.

\section{Effect of treatments on cabbage pests}

The ecology of insect pests is highly influenced by temperature, which may either enhance reproduction or decrease mortality of insects, leading to stronger infestations $[47,48]$. Climate dynamics can lead to the emergence of new species such as the South American tomato leaf miner Tuta absoluta (Meyrick) (Lepidoptera: Gelechiidae) that occurred in Europe [49]. Generally, intercropping, Piper emulsion and insecticide 
Table 4 Effect of planting dates-A (early, normal and late) and treatments-B (control, intercropping, Piper emulsion and insecticide) on number of sprouted cabbage plants (mean \pm SD)

\begin{tabular}{llll}
\hline A & & & \\
\hline Treatments & Planting dates & & \\
\cline { 2 - 4 } & Early & Normal $^{\mathbf{a}}$ & Late \\
\hline Control & $6.2 \pm 1.7 \mathrm{c}$ & $5.0 \pm 1.1 \mathrm{~b}$ & $0.7 \pm 0.9 \mathrm{a}$ \\
Intercropping & $0.5 \pm 0.5 \mathrm{~b}$ & $1.0 \pm 0.0 \mathrm{a}$ & $0.2 \pm 0.5 \mathrm{a}$ \\
Piper emulsion & $1.2 \pm 0.9 \mathrm{~b}$ & $1.0 \pm 0.5 \mathrm{a}$ & $0.0 \pm 0.0 \mathrm{a}$ \\
Insecticide & $1.0 \pm 0.9 \mathrm{~b}$ & $0.5 \pm 0.5 \mathrm{a}$ & $0.0 \pm 0.0 \mathrm{a}$ \\
\hline B & & & \\
\hline Planting dates & Treatments & & \\
\cline { 2 - 5 } & Control & Intercropping & $1.2 \pm 0.9 \mathrm{~b}$ \\
\hline Early & $6.2 \pm 1.7 \mathrm{c}$ & $0.5 \pm 0.5 \mathrm{~b}$ & $1.0 \pm 0.5 \mathrm{a}$ \\
Normal & $5.0 \pm 1.1 \mathrm{~b}$ & $1.0 \pm 0.0 \mathrm{a}$ & $0.0 \pm 0.0 \mathrm{a}$ \\
Late & $0.7 \pm 0.9 \mathrm{a}$ & $0.2 \pm 0.5 \mathrm{a}$ & \\
\hline Vallsion & \\
\hline
\end{tabular}

Values within rows with different letters are significantly different $(P<0.05)$

a Data taken from Tanyi et al. [35]

demonstrated efficacy as control measures for cabbage pests against the control, irrespective of the planting dates [18]. Tomato intercropping could be considered as the most affordable and cost-effective pest management strategy in relation to the other treatments. The impact of tomato intercropping is likely due to the confusing olfactory and visual cues from tomato plants that repelled cabbage pests $[18,50]$. P. guineense contains isobutyl amide plant secondary metabolites (e.g. piperine, piperiline and natural lipophilic amides) that act as neurotoxins in insects [51-53], which likely resulted in the efficacy of Piper emulsion against insect pests across planting dates. This effect of Piper emulsion on cabbage infestation and pest occurrence is consistent with reports on the efficacy of Piper [54, 55]. These results strongly support the second hypothesis of this study that advocates a combination of alternative planting dates and Piper emulsion or intercropping as farmlevel adaptation to control cabbage pests under current climate variability in the study area.

\section{Interactive effects of planting dates and treatments on cabbage}

Cabbage performance was consistent with the rate of pest infestation, with increased cabbage yield as pest infestation decreased and vice versa. The significantly low number of sprouted plants and high yield during late planting compared to normal and early plantings is consistent with the first hypothesis that suggests a shift in planting dates in the study area. This can be attributed to changes in climate variables such as temperature and rainfall that reduced pest larvae below economic threshold $[43,45]$. Cabbage performance is consistent with the second hypothesis of this study that advocates greater cabbage yield due to tomato intercropping as companion crop. Low cabbage yield in the control is consistent with high pest infestation, which corresponds to high leaf and head damage that likely reduced photosynthetic carbon fixation and plant growth [56]. Looper and webworm are considered major yield-reducing cabbage pests, which is consistent with the significant cabbage damage that is comparable to DBM damage, especially during early and late plantings [11]. The increasing cabbage yield from early to late plantings in Cabbage-tomato intercrop compared to insecticide and Piper treatments is inconsistent with the recorded trend of pest infestation, which suggests additional factors that improved cabbage yield. The decomposition of dead tomato plants after complete pest damage in the sole tomato and Cabbage-tomato intercrop treatments likely improved soil fertility, plant nutrition and biological processes that favoured cabbage yield [57]. Overall, the relatively high cabbage yield recorded in the late planting and cabbage-tomato intercrop treatment highlights the importance of integrating alternative planting dates and treatments under climate change scenarios.

\section{Conclusion}

The interaction of planting dates and Piper emulsion or intercropping treatments can be effectively used to control cabbage pests and improve yields, with the late 

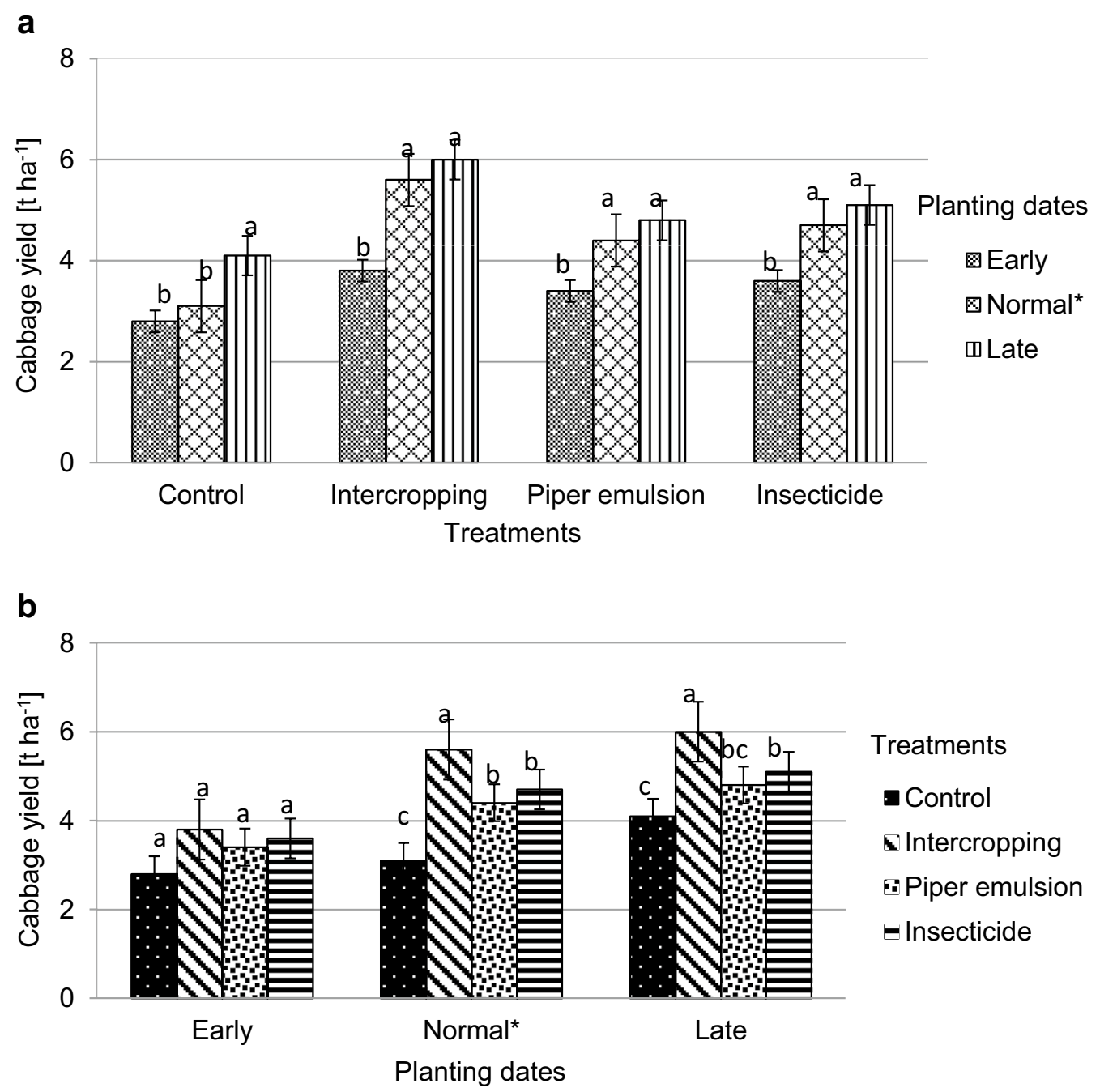

Fig. 3 Impact of planting dates (a) (early, normal and late) and treatments (b) (control, intercropping, Piper emulsion and insecticide) on cabbage yield ( $\mathrm{t} \mathrm{ha}{ }^{-1}$, mean $\pm \mathrm{SD}$ ); values within treatments or planting dates with different letters are significantly different $(P<0.05)$. ${ }^{*}$ Data from Tanyi et al. [35]

planting date as viable alternative farm-level adaptation to climate variability. These represent cost-effective and environmentally friendly pest management strategy that can be adopted by farmers to control cabbage pests below economic injury threshold and improve yield.

\section{Abbreviations}

DBM: diamondback moth; SSA: sub-Saharan Africa; PAMS: prevention, avoidance, monitoring and suppression; SD: standard deviation; ANOVA: analysis of variance; NPK: nitrogen, phosphorus and potassium.

\section{Authors' contributions}

This work was carried out in collaboration between all authors. CBT designed, established and managed the experiment, prepared botanical, performed harvest and data collection, processed and analysed data, performed literature searches and wrote the first manuscript draft. CN contributed in experimental design, data processing and statistical analyses, conducted literature searches and coordinated preparation of first manuscript draft. NNN contributed in the experimental design, coordinated the field experimentation and data collection, and supervised manuscript preparation and the overall study. All authors read and approved the final manuscript.

\section{Acknowledgements}

We extend gratitude to the Faculty of Agriculture and Veterinary Medicine, University of Buea, and the Ministry of Higher Education-MINESUP Cameroon for Research Grants.

\section{Competing interests}

The authors declare that they have no competing interests.

\section{Availability of data and materials}

All data generated or analysed during this study are included in this published article.

\section{Consent for publication}

Not applicable. 
Ethics approval and consent to participate

Not applicable.

\section{Funding}

Not applicable.

\section{Publisher's Note}

Springer Nature remains neutral with regard to jurisdictional claims in published maps and institutional affiliations.

Received: 22 September 2018 Accepted: 3 December 2018

Published online: 10 December 2018

\section{References}

1. Datta S. Impact of climate change in Indian horticulture - a review. Int J Sci Environ Technol. 2013;2:661-71.

2. Kotir JH. Climate change and variability in sub-Saharan Africa: a review of current and future trends and impacts on agriculture and food security. Environ Dev Sustain. 2011;13:587-605.

3. Kemausuor F, Dwamena E, Bart-Plange A, Kyei-Baffour N. Farmers' perception of climate change in the Ejura-Sekyedumase District of Ghana. J Agric Biol Sci. 2011;6:26-37.

4. Gornall J, Betts R, Burke E, Clark R, Camp J, Willett K, Wiltshire A. Implications of climate change for agricultural productivity in the early twentyfirst century. Philos Trans R Soc Br. 2010;365:2973-89.

5. Mirza MMQ. Climate change and extreme weather events: can developing countries adapt? Climate Policy. 2011;3:233-48

6. Bale J, Masters G, Hodkinson I. Herbivory in global climate change research: direct effects of rising temperature on insect herbivores. J Glob Change Biol. 2002;8:1-16.

7. Das DK, Singh J, Vennila S. Emerging crop pest scenario under the impact of climate change-a brief review. J Agric Phys. 2011;11:13-20.

8. Bagamba F, Bashaasha B, Claessens L, Antle J. Assessing climate change impacts and adaptation strategies for smallholder agricultural systems in Uganda. Afr Crop Sci J. 2012;20:303-16.

9. Lobell DB, Burke MB, Tebaldi C, Mastrandrea MD, Falcon WB, Naylor RL. Prioritizing climate change adaptation needs for food security in 2030. Science. 2008:319:607-10.

10. Mohammad FD, Fauziah I, Mohd RZ, Fairuz K, Abu ZU, Syed A, Rahman SAR, Ismail RM, Hanysyam MN, Norazliza R. Asymmetry effect of intercropping non host crops between cabbage and climatic factor on the population of the diamondback moth (Plutella Xylostella L.) and yield. J Agric For Fish. 2014;3:171-7.

11. Mochiah MB, Banful B, Fening KO, Amoabeng BW, Offei K, Bonsu E, Braimah $\mathrm{H}$, Owusu-Akyaw M. Botanicals for the management of insect pests in organic vegetable production. J Entomol Nematol. 2011;3:85-97.

12. Shelton AM, Wyman JA, Cushing NL, Apfelbeck K, Dennehy TJ, Mahr SER, Eigenbrode SD. Insecticide resistance of diamondback moth (Lepidoptera: Plutellidae) in North America. J Econ Entomol. 1993:86:11-9.

13. Shelton AM, Sances FV, Hawley J, Tang JD, Boune M, Jungers D, Collins $\mathrm{HL}$, Farias J. Assessment of insecticide resistance after the outbreak of diamondback moth (Lepidoptera: Plutellidae) in California. J Econ Entomol. 2000;93:931-6.

14. Susila W, Sumiartha K, Nemoto H, Kawai S. The effect of insecticides on populations of diamondback moth, Plutella xylostella (Lepidoptera: Yponomeutidae) and its parasitoid, Diadegma semiclausum (Hymenoptera: Ichneumonidae) in cabbage. J Int Soc Southeast Asian Agric Sci. 2003;9:132-8.

15. Sarfraz M, Keddie BA. Conserving the efficacy of insecticides against Plutella xylostella (L.) (Lepidoptera, Plutellidae). J Appl Entomol. 2005;129:149-57.

16. Xu QC, Xu HL, Qin FF, Tan JY, Liu G, Fujiyama S. Relay-intercropping into tomato decreases cabbage pest incidence. J Food Agric Environ. 2010;8:1037-41.

17. Dudley TS, Marvin KH, Liu TX. Adoption of pest management practices by vegetable growers. J Am Entomol. 2002;48:197-9.

18. Asare-Bediako E, Addo-Quaye AA, Mohammed A. Control of diamondback moth (Plutella xylostella) on cabbage (Brassica oleracea var capitata) using intercropping with non-host crops. Am J Food Technol. 2010;5:269-74.
19. Endersby NM, Morgan WC. Alternatives to synthetic chemical insecticides for use in crucifer crops. J Biol Agric Hortic. 1991;8:33-52.

20. Said M, Itulya FM. Intercropping and nitrogen management effects of diamondback moth and yield of collards in the highlands of Kenya. J Afr Crop Sci. 2003:2:35-42.

21. Syed TS, Lu YY, Liang GW. Effect of crude extracts from plants on the oviposition behavior of diamondback moth. J South China. 2003:24:87-8.

22. Liu S, Ji M, Zhao L, Wei S, Wang G, Li X, Li L. Preliminary study on bioactivity of two plant extracts against three kinds of pests. Xiandai Nongyao, Shenyang. 2007;6:27-9.

23. Li M, Gao X, Gao Z, Zhao W, Su Z. Insecticidal activity of extracts from fortyeight plants including Xanthium sibiricum Patrin. Huanjing Xuebao Jinan. 2008; 17:33-7.

24. Sayyed AH, Saeed S, Noor-Ul-Ane M, Crickmore N. Genetic, biochemical, and physiological characterization of spinosad resistance in Plutella xylostella (Lepidoptera: Plutellidae). J Econ Entomol. 2008;101:1658-66.

25. Tingem M, Rivington M, Bellocchi G, Azam-Ali S, Colls J. Assessment of the ClimGen stochastic weather generator at Cameroon sites. Afr J Environ Sci Technol. 2008;1:86-92

26. Tingem M, Rivington $M$, Azam-Ali S, Colls J. Effects of climate change on crop production in Cameroon. Climate Res. 2007;36:65-77.

27. Fombe L, Amahnui AG. Impacts of climate variability on malaria incidence in the Buea Municipality of Cameroon; implications for malaria control and prevention. Curr J Appl Sci Technol. 2017;25:1-6.

28. Laux P, Jäckel G, Tingem RM, Kunstmann H. Impact of climate change on agricultural productivity under rainfed conditions in Cameroon-a method to improve attainable crop yields by planting date adaptations. Agric For Meteorol. 2010;150:1258-71.

29. Ngondjeb YD. Agriculture and climate change in Cameroon: an assessment of impacts and adaptation options. Afr J Sci Technol Innov. 2013;5:85-94.

30. John P, lan DE, Robert WP, Laszlo N. Zonation of forest vegetation and soils of Mount Cameroon, West Africa. Plant Ecol. 2007;192:251-69.

31. Ngosong C, Mfombep PM, Njume AC, Tening AS. Comparative advantage of Mucuna and Tithonia residue mulches for improving tropical soil fertility and tomato productivity. Int J Plant Soil Sci. 2016;12:1-13.

32. Fraser PB, Brodie HM, Cheek MD, Healey SJ, Marsden JN, Nning NJ, McRobb A. Plant succession on the 1922 lava flow of Mt. Cameroon. In: Timberlake J, Kativu S, editors. African plants: biodiversity, taxonomy and uses. Richmond: Royal Botanic Garden, Kew; 1999. p. 253-62

33. Payton RW. Ecology, altitudinal zonation and conservation of tropical rainforest of Mount Cameroon. Final project-report. R4600, ODA, London; 1993.

34. Fraser PJ, Hall JB. Climate of the Mount Cameroon region, long and medium term rainfall, temperature and sunshine data, SAFS, University of Wales Bangor, MCP-LBG, Limbe; 1998. p. 56

35. Tanyi CB, Ngosong C, Ntonifor NN. Comparative effects of Piper guineense emulsion and Cabbage-tomato intercropping for controlling cabbage pests and improving performance. J Agric Ecol Res Int. 2017;13:1-12.

36. Nana C. Research methods and applied statistics: beginners and advanced learners. Buea: GOOAHEAD; 2012.

37. StatSoft. Statistica 9.1 for windows. StatSoft Inc. Tusla, USA; 2010.

38. Porter JH, Parry ML, Carter TR. The potential effects of climatic change on agricultural insect pests. J Agric For Meteorol. 1991;57:221-40.

39. Ngowi BV, Tonnang HEZ, Mwangi EM, Johansson T, Ambale J, Ndegwa PN. Temperature-dependent phenology of Plutella xylostella (Lepidoptera: Plutellidae): Simulation and visualization of current and future distributions along the Eastern Afromontane. Public Libr Sci. 2017;12:1-24.

40. Atwal AS, Dhaliwal GS. Agricultural pests of South Asia and their management. Ludhiana: Kalyani Publisher; 2002. p. 320.

41. Shukla A, Kumar A. The diamond back moth, Plutella xylostella a problematic pest of Brassica crop. J Adv Indian Entomol. 2005;1:229-40.

42. Menéndez R. How are insects responding to global warming. J Entomol. 2007;150:355-65.

43. Abril A, Oliveras J, Gomez C. Effect of temperature on the development and survival of the Argentine ant, Linepithema humile. J Insect Sci. 2010;10:1-13.

44. Stireman JO, Dyer LA, Janzen DH, Singer MS. Climatic unpredictability and parasitism of caterpillars: implications of global warming. Proc Natl Acad Sci. 2005;102:17384-7.

45. Emily AB, Heather AH, Brent JS, Rebecca HH, Jonathan AN. Winter warming effects on overwinter survival, energy use, and spring emergence of Cerotoma trifurcata (Coleoptera: Chrysomelidae). J Agric For Entomol. 2016:19:163-70. 
46. Estay SA, Lima M, Labra FA. Predicting insect pest status under climate change scenarios: combining experimental data and population dynamics modeling. J Appl Entomol. 2009;133:491-9.

47. Olesen JE, Bindi M. Consequences of climate change for European agricultural productivity, land use and policy. Eur J Agron. 2002;16:239-62.

48. Jamieson MA, Trowbridge AM, Raffa KF, Lindroth RL. Consequences of climate warming and altered precipitation patterns for plant-insect and multitrophic interactions. Plant Physiol. 2012;160:1719-27.

49. Van Damme V, Berkvens N, Moerkens R, Berckmoes E, Wittemans L, De Vis R, De Clercq P. Overwintering potential of the invasive leafminer Tuta absoluta (Meyrick) (Lepidoptera: Gelechiidae) as a pest in greenhouse tomato production in Western Europe. J Pestic Sci. 2014;88:533-41.

50. Krishna MPK, Srinivasan K. Indian mustard as a trap crop of major lepidopterous pests of cabbage. J Trop Pest Manag. 1991;37:26-32.

51. de Paula VF, de Barbosa LCA, Demuner AJ, Pilo-Valeso D, Picanço MC. Synthesis and insecticidal activity of new amide derivatives of piperine. J Pest Manag Sci. 2000;56:168-74.

52. Scott IM. Efficacy of Piper (Piperaceae) extracts for control of common home and garden insect pests. J Econ Entomol. 2004;97:1390-403.
53. Okonkwo CO, Ohaeri OC. Insecticidal potentials of some selected plants. J Chem Pharm Res. 2013;5:370-6.

54. Arong GA, Oku EE, Obhiokhenan AA, Adetunji BA, Mowang DA. Protectant ability of Xylopia aethiopica and Piper guineense leaves against the cowpea bruchid Callosobruchus maculatus (fab.) (Coleoptera: Bruchidae). World J Sci Technol. 2011;1:14-9.

55. Akunne CE, Afonta CN, Mogbo TC, Ononye BU, Ngenegbo UC. Evaluation of the efficacy of mixed powders of Piper guineense and Zingiber officinale against Callosobruchus maculatus (F.) (Coleoptera: Bruchidae). Am J Biol Life Sci. 2014;2:63-7.

56. Pavel IK, Brian F, Christine HF, Robert DH. Plant responses to insect herbivory: interactions between photosynthesis, reactive oxygen species and hormonal signalling pathways. J Plant Cell Environ. 2012;35:441-53.

57. Pane C, Celano G, Piccolo A, Villecco D, Spaccini R, Palese AM, Zaccardelli $M$. Effects of on-farm composted tomato residues on soil biological activity and yields in a tomato cropping system. J Chem Biol Technol Agric. 2015;2:1-13.

\section{Submit your manuscript to a SpringerOpen ${ }^{\odot}$ journal and benefit from:}

- Convenient online submission

- Rigorous peer review

- Open access: articles freely available online

- High visibility within the field

- Retaining the copyright to your article

Submit your next manuscript at $\gg$ springeropen.com 